\title{
Diatom-based evidence for abrupt climate changes during the Late Glacial in the Southern Carpathian Mountains
}

\author{
Krisztina Buczkó* \\ Department of Botany \\ Hungarian Natural History Museum, Budapest \\ Éva Soróczki-Pintér \\ Department of Botany \\ Hungarian Natural History Museum, Budapest \\ Department of Limnology, \\ University of Pannonia, Veszprém \\ Mihály Braun \\ University of Debrecen, Department of Inorganic \\ and Analytical Chemistry, Debrecen
}

\author{
Enikő K. Magyari \\ Hungarian Academy of Sciences - Hungarian \\ Natural History Museum Research Group for \\ Paleontology, Budapest \\ Katalin Hubay \\ Department of Inorganic and Analytical Chemistry \\ University of Debrecen, Debrecen
}

\author{
Miklós Bálint \\ Biodiversität und Klima Forschungszentrum \\ Frankfurt am Main, Germany
}

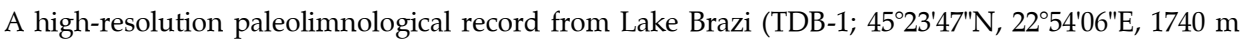
a.s.l.), a small, glacial lake in the Retezat (South Carpathian Mountains, Romania) provides a sensitive record of the impacts of late glacial climatic change on siliceous algal assemblages. The sequence, ranging from 15,700 cal yr $\mathrm{BP}$ to $9500 \mathrm{cal} \mathrm{yr} \mathrm{BP}$, suggests that the most significant changes in diatom assemblages took place at 12,800 and 10,400 cal yr BP, when alkaliphilous fragilarioid taxa were replaced by acidophilous diatoms. Altogether eight zones were distinguished with sharp and rapid changes of diatom assemblages. The paper discusses the application of siliceous algae in multi-proxy paleolimnological analyses, demonstrates the advantages and disadvantages of this proxy and presents the story of floristic discovery of unique diatom assemblages, the closest recent analogs of which are found in the arctic region.
\end{abstract}

Key words: diatoms, glacial lakes, oligotrophy, Retezat Mountains, paleolimnology

\section{Introduction}

Recent concern over the effects of climate change has focused scientific and public attention on sensitive paleoenvironmental records worldwide, including extreme environments, such as the High Arctic and Antarctica, as well as pristine,

\footnotetext{
Addresses: K. Buczkó, É. Sóroczki-Pintér: H-1476 Budapest, P.O. Box 222, Hungary

E. Magyari: H-1476 Budapest, P.O. Box 222, Hungary

K. Hubay, M. Braun: H-4010 Debrecen, P.O. Box 21, Hungary

M. Bálint: Senckenberganlage 25, D-60325 Frankfurt am Main, Germany

Received: July 15, 2010; accepted: September 13, 2010

* Corresponding author: E-mail: buczko@bot.nhmus.hu
} 
remote alpine regions (Pienitz et al. 1995; Stoermer and Smol 1999; Schmidt et al. 2004, 2006; Antoniades et al. 2008). Cold, sparsely inhabited regions provide favorable conditions for cryptogams and small-sized animals, but these groups are rarely the objectives of taxonomical studies, while for instance vascular plants are much better studied. Nevertheless, resistant body parts of algae, mosses, macro-invertebrates and sponges are preserved in lake sediments (so-called biotic proxies), providing excellent possibilities for better understanding the functioning of natural systems, as well as being useful for making environmental reconstructions (Smol 2008). Their remnants in lake sediments open a time window for short (a couple of years, decades or hundreds of years) or long-term (thousand to million years) histories of lake ecosystems. The rich biotic evidence preserved in lake sediments of remote alpine lakes plays a distinguished role in the reconstruction of past ecosystem reactions including abrupt climate changes (Lotter et al. 1997, 1998; Schmidt et al. 2004, 2006).

The quality of reconstruction increases with the number of proxies applied. Each proxy reflects environmental change at its own scale and has advantages and disadvantages (Lotter 2003). Siliceous algae (diatoms and crysophycean statospores) are one of the most often studied biotic proxies. Scientists agree and emphasize that, although many inference models have recently been developed for fine paleoenvironmental reconstructions (so-called transfer functions), only little attention has been paid to the quality of the primary data on which the reconstructions are based (Mackay et al. 2005; Antoniades et al. 2008; Ryves et al. 2009).

In this paper we introduce the reader to the advantages and disadvantages of diatom-based reconstructions, to show the difficulties and uncertainties but also the beauties of diatoms in the example of a glacial lake in the Retezat Mts. We present our attempts, carried out since 2007, to build the best database for paleoenvironmental reconstruction. Our work can be regarded as if we were zooming in on a subject. While moving from a low-resolution analysis to a highresolution analysis, we refined the amplitude and spanning of changes along the time scale and then improved our knowledge of mountain diatom taxa, permitting a more precise reconstruction.

\section{Diatom analyses of the sediments of Lake Brazi}

In order to become familiar with the diatom flora of Lake Brazi, a lowresolution study of the diatom samples was carried out in 2008 (at 8-12 cm resolution, representing 500 to 1000-year steps) and detailed photo documentation was made. It became rapidly clear that some small-celled taxa were present in the sediments which are very similar under the light microscope (LM). Our first impression was that there is a sharp difference between the Late Glacial and Holocene sequences, the first one being dominated by fragilaroid taxa and the second one by the Aulacoseira species. This recognition was followed 
by some work to clear up the taxonomic diversity of this dominant group (Buczkó et al. 2010).

The second part of the analysis of Lake Brazi took place in the fall and winter of 2008 and the beginning of 2009, when species-level identifications were made every $4-8 \mathrm{~cm}$ (representing a time resolution of 300-600 years). During the counting procedure it was realized that LM is insufficient for correct identifications at species level, so groupings were made on generic level during the first analysis. Three zones were differentiated with $2-5$ sub-zones on the basis of the generic level diatom analyses. The most characteristic changes were found at ca. 10,150 and $5800 \mathrm{cal} \mathrm{yr} \mathrm{BP.} \mathrm{Below} 588 \mathrm{~cm}(14,266 \mathrm{cal} \mathrm{yr} \mathrm{BP})$ no diatoms were found (Buczkó et al. 2009). Our results were in agreement with the traditionally accepted view, as the Holocene (encompassing the last 11,500 years) is a stable period in terms of climatic conditions, especially when compared with the abrupt climate changes of the Late Glacial period. Further division into sub-zones resulted in additional zone boundaries at ca. 12,350, 10,800 and 9,800 cal yr BP.

This finding highlighted the need for high-resolution analysis in the Late Glacial and Early Holocene parts of the section (approximately between 15,755 $9500 \mathrm{cal} \mathrm{yr} \mathrm{BP).} \mathrm{As} \mathrm{a} \mathrm{third} \mathrm{step} \mathrm{therefore,} \mathrm{every} \mathrm{centimeter} \mathrm{was} \mathrm{sampled,} \mathrm{and}$ counted using LM as well as SEM (in this way we obtained a record from every 16 to 104 years). By the end of 2009 it became clear that several insufficiently described or new species are in the section. The material published in this study was made on the basis of species-level identifications. It must, however, be emphasized that we are far from completing the diatom study of Lake Brazi. Taking into account the results of other proxies (chironomids, cladoceran remains) that inferred lake stage even before $14,510 \mathrm{cal} \mathrm{yr} \mathrm{BP}(588 \mathrm{~cm})$, we very carefully scanned the deepest layers searching for siliceous remains. After dayslong scanning of the slides some remains were actually found. In this paper we present the results of high-resolution analysis from the Late Glacial part of the cored section.

\section{Material and Methods}

\section{Study site}

The Retezat is the wettest massif in the Romanian Carpathians, due to Mediterranean and oceanic influences. As a result the effects of the last glaciations have been more significant here than elsewhere in the South Carpathians. Numerous glacial lakes were formed as a result of the retreat of the ice in the subalpine and alpine belts, mainly during the Late Glacial (Reuther et al. 2007). Diatom assemblages from these lakes and their sediments were first studied by Péterfi (1974). Recently diatoms of pre-industrial times and the present day were compared in order to show biological and limnological changes 
within five lakes of the district (Clarke et al. 2005). More information on the studied lakes and the aim of the PROLONGE (Providing long environmental records of Late Quaternary climatic oscillations in the Retezat Mountains) project can be found in Magyari et al. (this issue).

\section{Methods}

A 490-cm long sediment core was taken in 2007 with a Livingston piston corer from the deepest part of the shallow lake (1 meter average water depth). Water depth at the coring point was $110 \mathrm{~cm}$; the base of the core is thus at $600 \mathrm{~cm}$ below lake surface level. Sampling and boundary depths hereafter are given in depths below the surface of the lake, not from the top of the sedimentary column. For sub-sampling, the plastic tubes containing the sediment were cut into halves and sub-samples were taken at 1-4 cm intervals for multi-proxy analyses, including pollen, macrofossils, cladocera, chironomid, geochemical properties and siliceous algae (Magyari et al., this issue). For analyses of siliceous algae, samples were prepared using standard digestion procedures (Batterbee 1986). Aliquotevaporated suspensions were embedded in Zrax (refractive index 1.7). At least 300 valves were counted in 87 samples using a light microscope (LEICA DM LB2 with 100 HCX PLAN APO). Diatom stratigraphies were zoned using CONISS as implemented in the Psimpoll 3.00 software (Bennett 2005). To confirm the validity of the quantitative zonation by CONISS, diatom zones were also delimited using binary splitting by sums-of-squares. The two methods gave very similar result; therefore the CONISS zones were kept.

Loss-on-ignition (LOI) analysis was used to determine the organic content of the sediment. It was carried out on $1 \mathrm{~cm}^{3}$ samples at $550{ }^{\circ} \mathrm{C}$ following the recommendations of Heiri et al. (2001). LOI was measured at $1 \mathrm{~cm}$ intervals.

Biogenic silica was extracted from a $20 \mathrm{mg}$ homogenized dry sample using $10 \mathrm{~cm}^{3} 0.2 \mathrm{~mol} \mathrm{dm}{ }^{-3}$ sodium hydroxide at $90^{\circ} \mathrm{C}$ for 2 hours. Measurement of silica and aluminum were made by ICP-OES. Dissolution of minerogenic silicates was negligible; thus alumina correction was not applied. Biogenic silica was expressed as percentage of dry weight.

\section{Results}

More than 150 taxa were distinguished in 87 samples that were suitable for quantitative analysis. Several taxonomical questions remained open and require a more detailed study. Consequently the number of taxa may either increase or decrease in the future. Many similar, small-celled species were found in the Late Glacial part of the core. The most characteristic diatoms are presented in Plates $1-4$, in the sequence of diatom assemblage zones. 
Late Glacial diatom assemblage zones of Lake Brazi

Eight zones were differentiated on the basis of the 31 most abundant taxa (Fig. 1 ). The most significant diatom assemblage changes were found at ca. 10,400 and 12,800 cal yr BP.

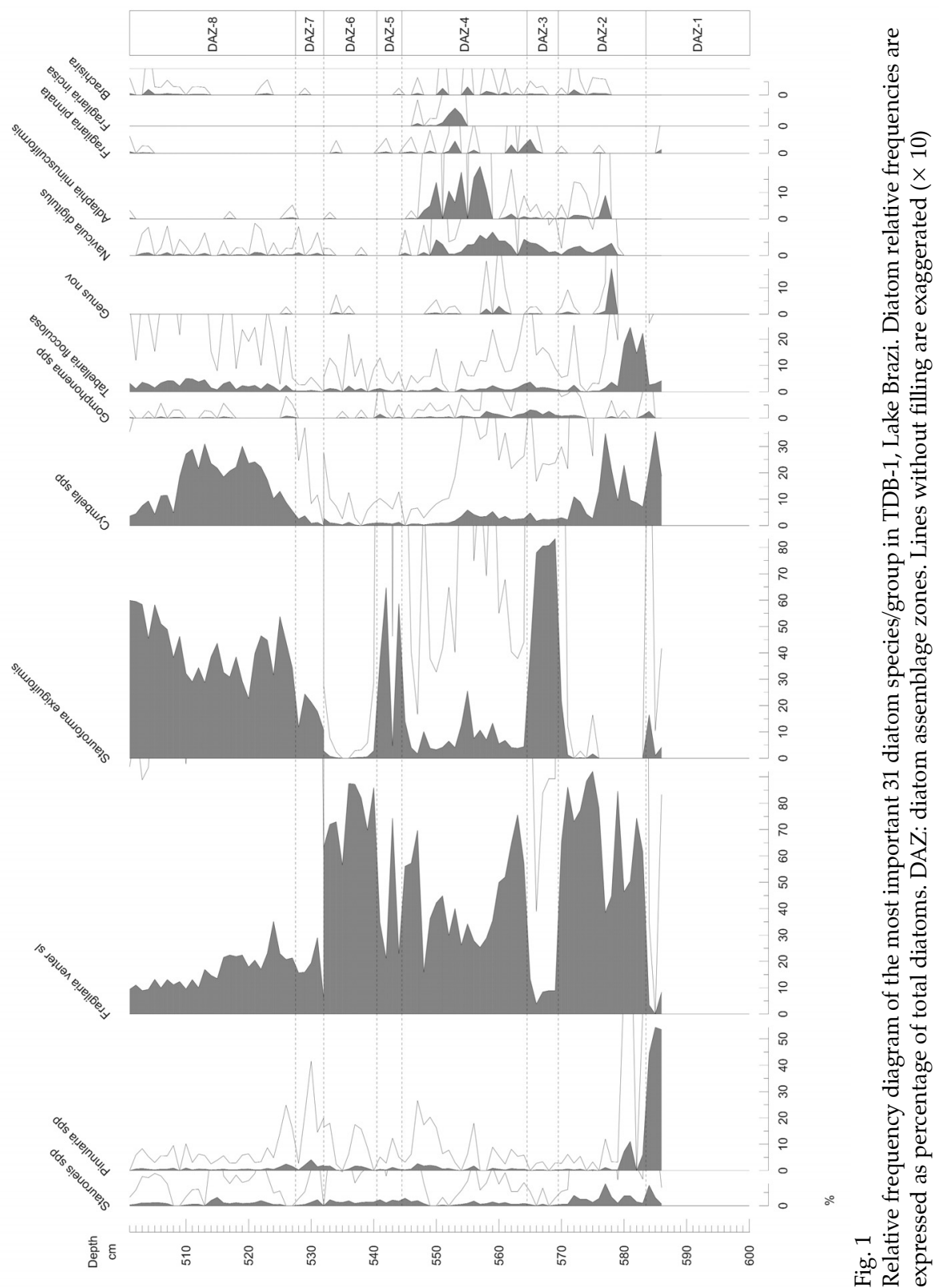


Diatom assemblage zone - DAZ-1

600-583.5 cm (15,755-14,067 cal yr BP) Plate 1 - Figs 1-24

The first diatom assemblage zone can be divided into two significantly different sub-zones: in the first one, the occurrences of siliceous algae are sporadic (600-586.5 cm; ca. 15,755-14,364 cal yr BP), while in the second subzone (586.5-583.5 cm / 14,364-14,067 cal yr BP) more remains were found (Plate 1).

There were not enough valves in the deepest part of the core for statistical analysis, but with careful scanning some dissolved remains of siliceous algae were detected. Already the first samples bore some chrysophyceaen cysts, and fragmented, dissolved diatoms (Plate $1-$ Figs $1-7)$. The preserved parts of the valves (so-called sternums; Plate 1 - Figs 5, 7, 8 and the inner ring of Aulacosiera taxa, the so-called ringleiste $=$ Fig. 3 ) are the strongest and most resistant parts of the frustules where the expressed silicification was detected. These findings suggest that in this very early stage of the lake development several diatom taxa were already present. Not only small-celled species $(<10 \mu \mathrm{m})$, but also large, heavy diatom taxa inhabited barren surfaces on the lakeshore, and the open water of the glacial lake. Pinnularia borealis (Fig. 6) is known as an aerophytic species, but in Fig. 5 a Stauroneis sternum and in Fig. 7 central area of a cymbelloid species can also be recognized. These diatoms live in water and thus support lake conditions with at least a short partial ice-free period.

At $596 \mathrm{~cm}$ some lotic (taxa living in running water) forms were found (Hannea arcus (Ehr.) Patrick, Plate 1 - Fig. 10), indicative of flowing water. Small brooklets likely flowed into the lake. The diatom assemblages at $587 \mathrm{~cm}$ were rich in aerophytic taxa, e.g. Pinnularia borealis Ehr., Hantzschia amphyoxis (Ehr.) Grunow, Orthoseira roseana (Rabenhorst) O'Meara, Diadesmis sp. (Plate 1 - Figs 11-18). These diatoms live on bare stone surfaces, cliffs, and likely indicate a small water body that did not support a diverse aquatic diatom assemblage, but where several terrestrial species were washed into it. In Plate 1 (Figs 19-24) we present a photo series demonstrating the different phases of dissolution. In Fig 19, only the strongest, central part of the valves can be observed, while in Figs 20-21 the striation of Pinnularia species is also visible, but the edge of the valves (where the valves are thicker) is better recognizable. In this phase, the characteristic features of species are sufficient for species-level identification; the identity of Pinnularia microstauron s.l. is clear in Figs 22-23, and especially in Fig. 24.

Plate $1 \rightarrow$

Figures 1-24. Siliceous remains obtained from the DAZ-1 of Lake Brazi. Fig. 1. Crysophyceaen statospora Fig. 2. Staurosira veneta, Fig. 3. Aulacoseira sp., Ringleiste, Fig. 4. probable Aulacoseira mantle view, Fig. 5. Stauroneis sternum, Fig. 6. Pinnularia borealis, Fig. 7. sternum of a cymbelloid species, Fig. 8. Stauroneis sternum, Fig. 9. Hannea arcus, Fig. 10. Ulnaria ulna, Figs 11-12. Pinnularia borealis. Figs 13-14 Hantzschia amphyoxis, Figs 15-16. Orthoseira roseana, Figs 17-18. Diadesmis sp. Figs 19-24. series of the corosion of Pinnularia species. Fig. 9. reofil indicator, prefers flowing water. Figs 11-18. aerophytic species. Figs 1-7. TDB-1 600 cm, Figs 8-10. TDB-1 596 cm, Figs 11-24. TDB-1 $587 \mathrm{~cm}$, Scale bar $=10 \mu \mathrm{m}$ 
Abrupt climate changes during the Late Glacial in the Southern Carpathian Mountains 255
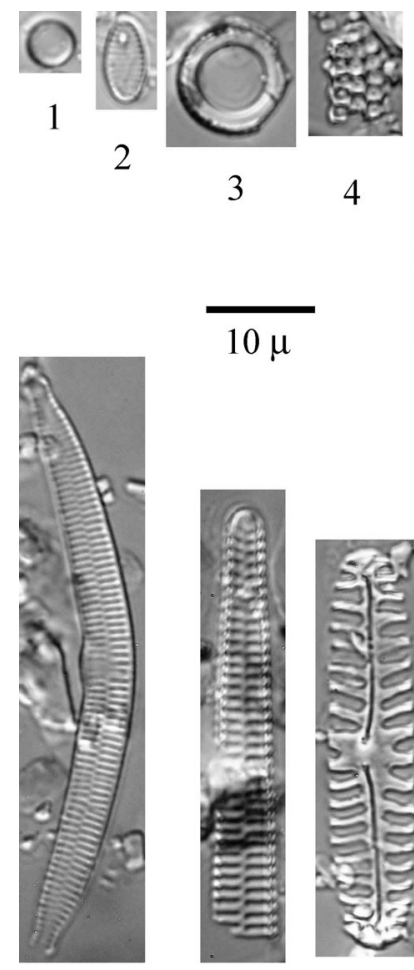

9

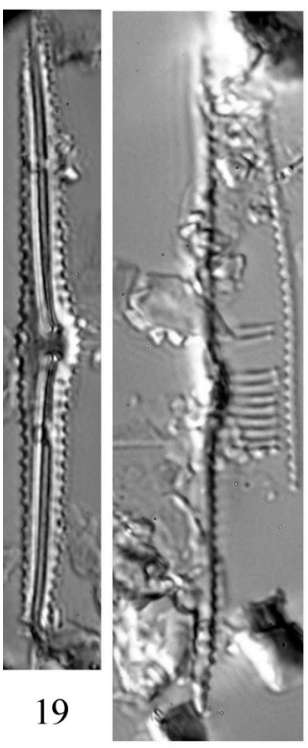

20
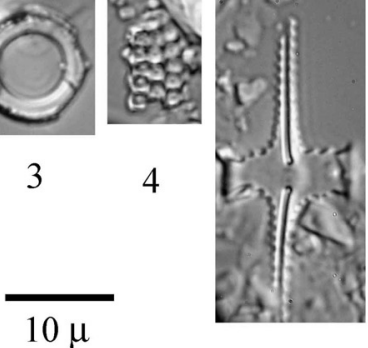

5

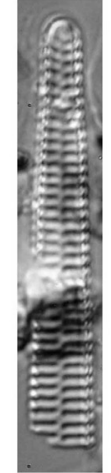

10

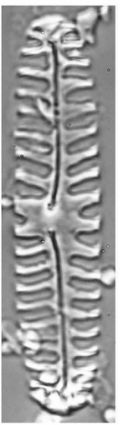

$11 \quad 12$

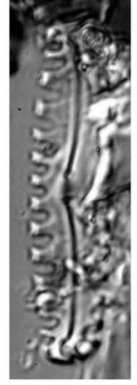

6
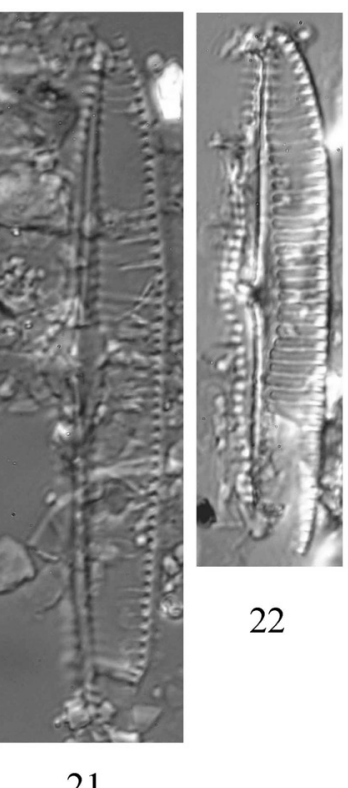

22

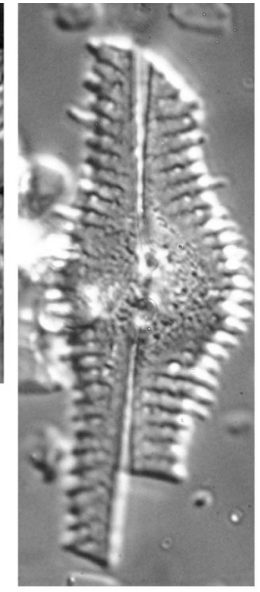

7

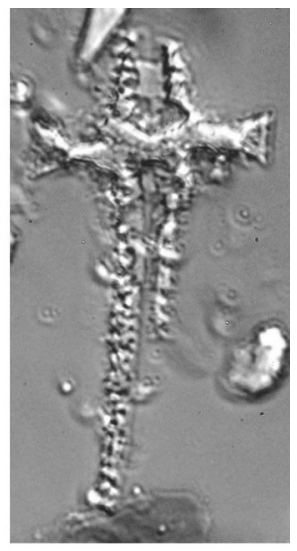

8
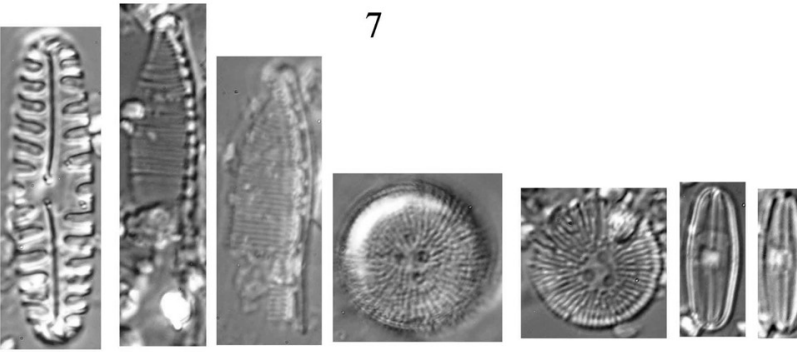

15

$17 \quad 18$

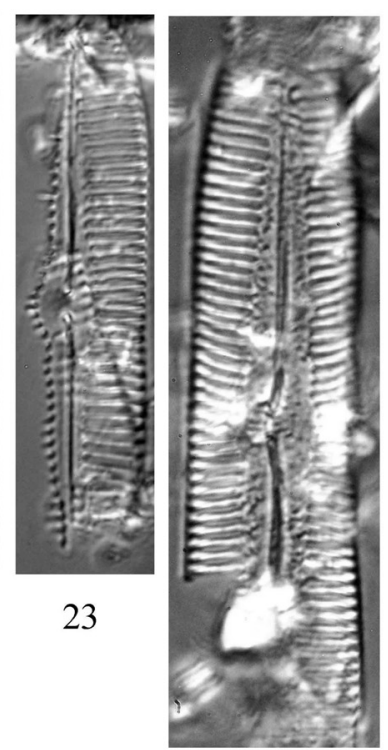

24

Central European Geology 52, 2009 
In the second sub-zone (586.5-583.5 cm / 14,364-14,067 cal yr BP) valves are more abundant and thus samples were suitable for counting. Nonetheless the high portion of sternum suggests poor preservation. Notable is the high abundance of Encyonema species [E. silesiaca (Bleisch) Mann (Plate 2 - Figs 19-21); Cymbopleura amphicephala Krammer (Plate 2 - Fig. 22)]. The relative frequency of chrysophyceaen cysts is also high in this zone, but they were probably found more often because of their resistant, round shape, and the easily identifiable resting spores. This siliceous algae assemblage suggests a permanent water body with increasing planktonic habitats and poor nutrient availability.

Diatom assemblage zone - DAZ-2

583.5-569.5 cm (14,067-12,781 cal yr BP) Plate 2 - Figs 1-25

From 14,067 cal yr BP the diatom record indicates the dominance of small, fragilaroid taxa. The most abundant species in this zone is a small-celled, more or less elliptical form, Staurosira venter s.l. (Ehr.) Cleve and Moeller (Plate 2 - Figs $1-8)$. It is one of the most often reported species that can colonize newly-formed lakes. It can form chains that lead to the multiplication of its size. Cymbelloid species are also well represented in the diatom vegetation. The most abundant representative of this group is Encyonema silesiaca, but Cymbopleura amphicephala is also a constant member of the assemblage. Both species have a $\mathrm{pH}$ optimum around 8 (Antoniades et al. 2008) suggesting alkali-rich water conditions. Several Stauroneis taxa (Plate 2 - Figs 9-11) contribute to the diverse flora of DAZ-2. A small but characteristic relative frequency peak was detected at ca. 13,500 cal yr $\mathrm{BP}$, when a peculiar, small, asymmetric diatom was recognized with a special raphe pattern (Fig. 12, bottom). It seems that this form has not been found elsewhere, and thus requires detailed taxonomical study, which could result in a new genus for science (Plate 2 - Figs 12-18). High abundance of Tabellaria flocculosa (Roth) Kütz. is also characteristic for this zone. The diatom assemblage in this and the previous zone represents the Bølling/Allerød interstadial (GI-1) that commenced ca. 14,500 cal yr BP (Björck et al. 1998). The diatom assemblages suggest that true aquatic conditions were only developed since ca. 14,100 cal yr BP in Lake Brazi, when the increasing dominance of Staurosira venter s.l. indicates benthic diatom abundance and silty lake bottom substrate. Cymbelloid taxa furthermore suggest the presence of thelmatophytes or mosses either on the

Plate $2 \rightarrow$

Figures 1-31. Diatoms from the DAZ-2 (Figs 1-25) and DAZ-3 (Figs 26-31) of Lake Brazi. Figs 1-8. Staurosira venter s.l. (Ehrenberg) Cleve and Moeller 1881. Figs 9-11. Stauroneis spp. Figs 12-18. Unknown diatom, probably new to science referred to as Genus sp. in Fig. 1. Figs 19-21. Encyonema silesiaca, Fig. 22. Cymbopleura amphicephala, Figs 23-25. terratological forms of Tabellaria flocculosa, Figs 26-31. Stauroforma exiguiformis. Scale bar $=10 \mu \mathrm{m}$ 
Abrupt climate changes during the Late Glacial in the Southern Carpathian Mountains 257

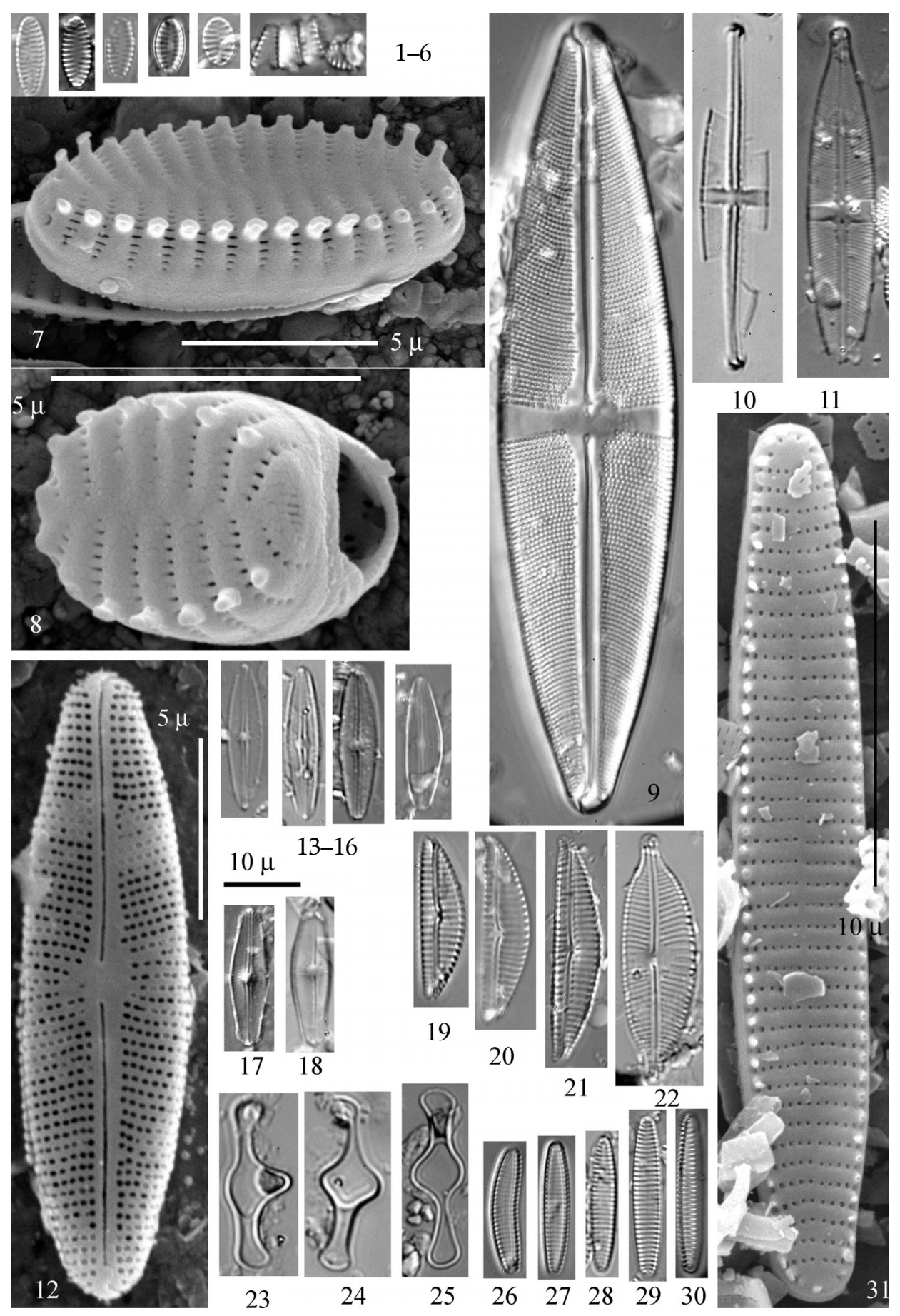

Central European Geology 52, 2009 
lakeshore or in the water. Note however that macrofossils of aquatic plants and lakeshore mosses were not found in the sediment (Magyari et al., in prep).

The end of DAZ-2 (cc. 12,781 cal yr BP) is very near to the climatic event around 12,800 cal yr BP, known as the Younger Dryas climatic reversal (GS-1; Björck et al. 1998).

Diatom assemblage zone - DAZ-3

569.5-564.5 cm (12,781-12,331 cal yr BP) Plate 2 - Figs 26-31

This zone is characterized by the dominance of Stauroforma exiguiformis (LangeBertalot) Flower (Plate 2 - Figs 26-31), Staurosira venter, and Navicula digituloides Lange-Bertalot. Cymbelloid taxa were also found, but their relative frequencies are low. Organic matter and biogenic silica content is slightly lower in this phase, and these proxies altogether suggest decreasing in-lake productivity.

Diatom assemblage zone - DAZ-4

$564.5-544.5 \mathrm{~cm}(12,331-11,052 \mathrm{cal}$ yr BP) Plate 3 - Figs 1-32

This zone is characterized by a diverse diatom flora with several small forms. The small-celled forms caused difficulties during the counting procedure, since the size-uniformity hides an extremely rich taxonomical diversity. Most of the dominant taxa presented on Plate 3 are $<10 \mu \mathrm{m}$, while the diatom valves $>20 \mu \mathrm{m}$ can be regarded as exceptions. The abundant taxa were: Adlaphia minuscula (Grunow) Lange-Bertalot, Navicula digituloides (Plate 3 - Figs 14-15), Navicula elorantana Lange-Bertalot (Plate 3 - Figs 29-32), Navicula schmassmannii Hustedt, Sellaphora spp. (Plate 3 - Figs 1-5, 23-28), Pseudostaurosira cf. brevistriata (Grunow in Van Heurck) D.M. Williams et Round (Plate 3 - Figs 19-22), small-round fragilaroid species (Plate 3 - Figs 19-22), Navicula cf. notha Wallace, Brachysira sp. Noteworthy is the unusual shape of Fragilaria incisa (C.S. Boyer) Lange-Bertalot (Plate 3 - Figs 6-9, 18) that at first sight can be regarded as a teratological form of Fragilaria capucina Desm. It is known from acidic waters.

Diatom assemblage zone - DAZ-5

$544.5-540.5 \mathrm{~cm}(11,052-10,901$ cal yr BP)

Zone 5 is characterized by the recurring dominance of the slightly acidophilous Stauroforma exiguiformis (Plate 2- Figs 26-31) that outgrew other diatoms for five

Plate $3 \rightarrow$

Figures 1-32. Main diatom species of DAZ-4 of Lake Brazi. Figs 1-5. Sellaphora sp. (planned to be published as S. rosenstockiiformis nova sp.), Figs 6-9, 18. Fragilaria incisa, Fig. 10. Navicula schmassmannii, Figs 11-13. Adlafia minuscula, Figs 14-15. Navicula digituloides, Figs 16, 17. Pseudostaurosira cf. brevistriata, Figs 19-22. "Fragilaria round" indet, small fragilaroid taxa, Figs 23-28. Sellaphora pupula group, Figs 29-32. Navicula(dicta) elorantana. Scale bar $=10 \mu \mathrm{m}$ 
Abrupt climate changes during the Late Glacial in the Southern Carpathian Mountains 259

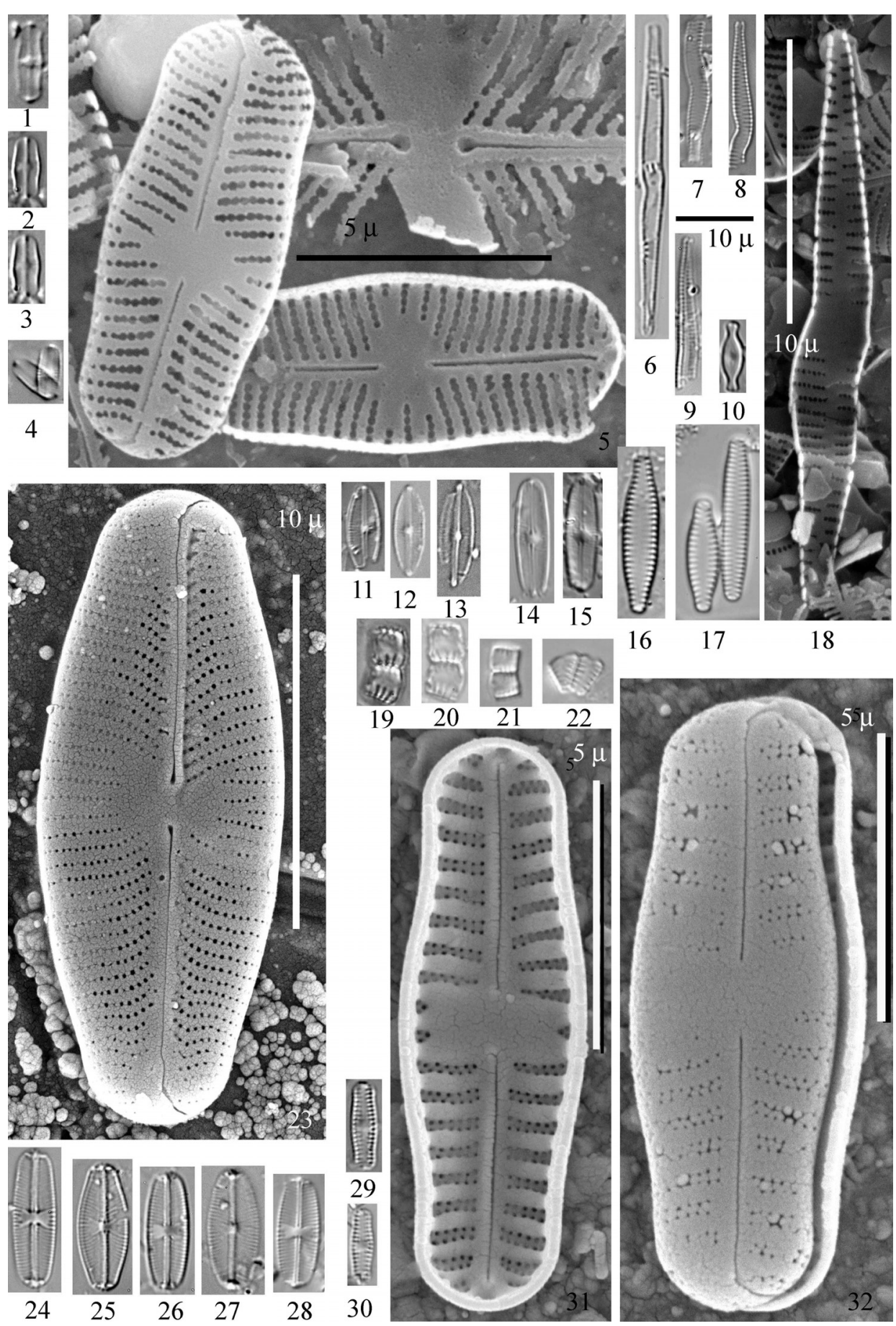

Central European Geology 52, 2009 
centuries. The dominance of $S$. exiguiformis coincides with a slight increase in biogenic silica content and suggests that lake productivity increased from ca. $11,050 \mathrm{cal} \mathrm{yr} \mathrm{BP}$, as is also indicated by the increase of green algae (Botryococcus, Pediastrum boryanum (Turpin) Meneghini, P. integrum Nägeli, P. alternans Nygaard).

Diatom assemblage zone - DAZ-6

$540.5-532 \mathrm{~cm}(10,901-10,514$ cal yr BP)

The small-celled Staurosira venter is dominant, and only another small-celled diatom contributed significantly to the assemblage, an unidentified Navicula form that is very similar to Navicula elorantana, but significantly larger. Diatom diversity was low, but the biogenic silica content increased. During additional scanning of the slides to check diatom diversity we detected the presence of some very large diatom valves in the samples, but during the standard counting procedure these large-celled diatoms were not encountered, or were only occasionally recorded. Some Pinnularia species, as long as $300 \mu \mathrm{m}$ and with heavily silicified valves, flourished in this period with Neidium amphigomphus s.l. (Ehr.) Pfitz. The biogenic silica content of a large valve can be thousandfold higher than that of a small, weak, fragile one.

Diatom assemblage zone - DAZ-7, 532-527.5 cm (10,514-10,387 cal yr BP) Plate 4 - Figs 5-7

DAZ-7 covers ca. 130 years and is characterized by a gradual increase of the slightly acidophilous Stauroforma exiguiformis and the dominance of a small Sellaphora species, which is very similar to S. seminulum (Grunow) D.G. Mann; however, the identity of this taxon requires further SEM study. However, the genus Sellaphora has become a model system for studies of species concept, as its identification is problematic. Several different small-celled forms were identified in this study as Sellaphora. In the history of diatom taxonomy these simplystructured, bilaterally symmetrical, raphid diatoms were usually classified in the genus Navicula. There is nothing particularly unusual about the structure in Sellaphora that sets it apart from all other "naviculoid" diatoms (Mann et al. 2008), but the chloroplast morphology (single plastid, H-shaped, lying with its center against the epivalve) and the reproductive characteristics separate the genus. In

Plate $4 \rightarrow$

Figures 1-32. Characteristic diatom species of DAZ-7 - DAZ-8 of Lake Brazi. Fig. 1. Frustulia saxonica, Fig. 2. Stenopterobia delicatissima, Fig. 4. Eunotia exigua, Figs 5-7. Achnathidium cf. minutissimum, Figs 8-10, 15. Encyonema gracilis, Figs 11-14. Sellaphora seminulum group, Figs 16-18, 21, 24-25. Aulacoseira nivalis (W. Smith) English and Potapova, Figs 19, 20, 22, 23. Aulacoseira laevissima (Grunow) Krammer Scale bar $=10 \mu \mathrm{m}$ 
Abrupt climate changes during the Late Glacial in the Southern Carpathian Mountains 261

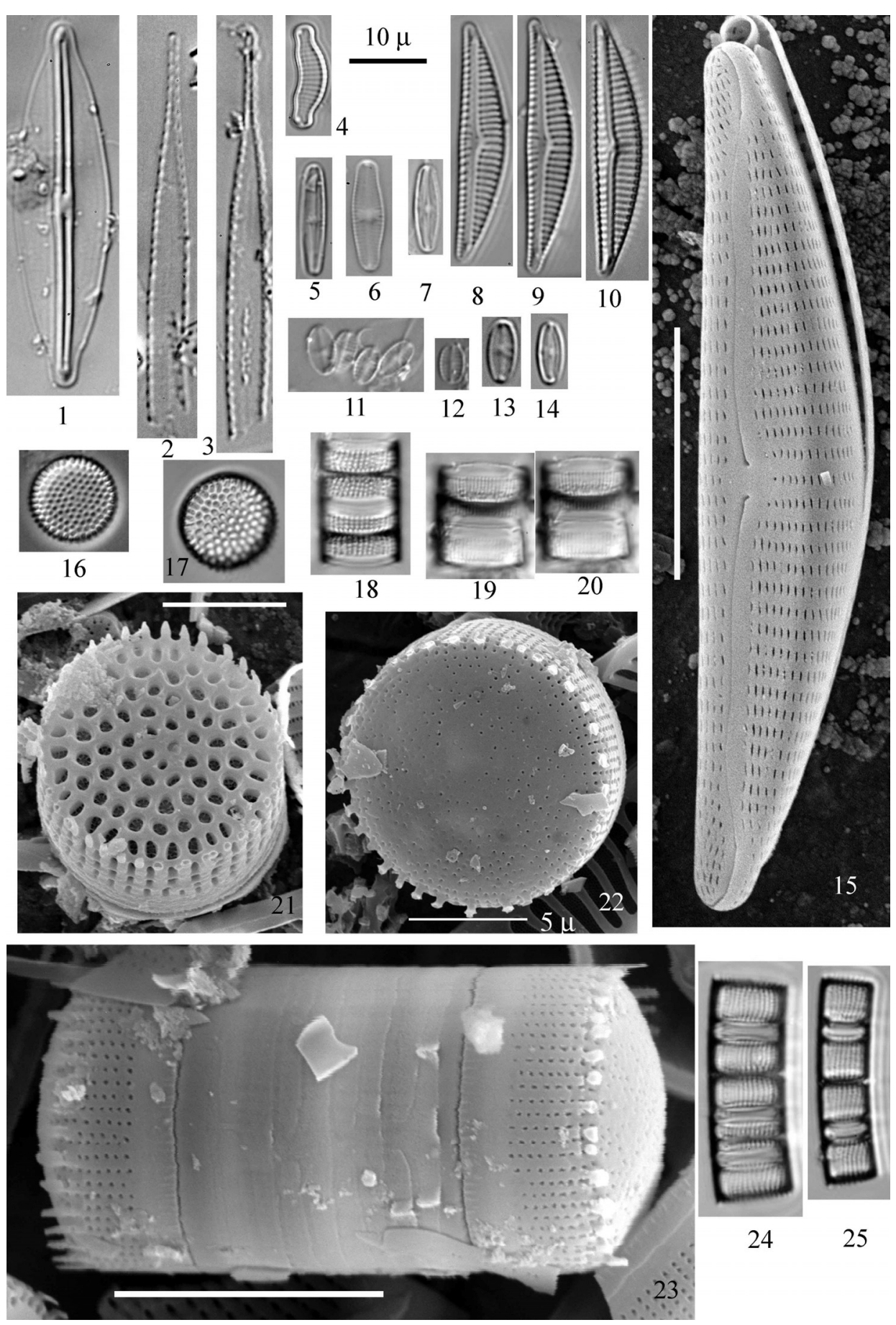

Central European Geology 52, 2009 
fossil samples neither the chloroplasts nor the reproductive phases can be observed, so the only feature that we can take into consideration is the structure of poroids that are small and round (Plate 3 - Fig. 5, Fig. 23). Sellaphora species often occurred in the sediment-derived epipelon.

Diatom assemblage zone - DAZ-8

527.5-501 cm (10,387-9956 cal yr BP) Plate 4 - Figs 1-4, 8-25

DAZ-8 represents a time of significant and basic changes in the diatom assemblages. After the continuous and virtual competition between the two most dominant species, the alkalophilous Staurosira venter and slightly acidophilous Stauroforma exiguiformis, it seems that the second species expanded successfully. The return of Tabelleria flocculosa, together with bog-diatoms, e.g. Frustulia saxonica Rabenhorst (Plate 4 - Fig. 1), Stenopterobia delicatissima (Lewis) Brébisson ex Van Heurck (Plate 4 - Figs 2), and Eunotia exigua (Bréb.) Rabenh. (Plate 4 - Fig. 4) point to the acidification of the lake water and the establishment of Sphagnum species around the lake. Rapid increase of Encyonema species (Plate 4 - Figs 8-10) is also a sign of the diversifying habitats. Meso-eutrotraphenic Nitzschia species with Achnathidium minutissimum (Kützing) Czarnecki indicate more mesotrophic lake conditions. In this zone the sharp increase of Aulacoseira taxa (Plate 4 - Figs 16-25) point to increasing water level.

\section{Discussion}

The aim of the multi-proxy analyses of the sediment of Lake Brazi is to provide a high-resolution environmental reconstruction for periods that show abrupt and/or rapid climate change. We use the term "abrupt change" following the recommended definition by the Committee on Abrupt Climate Change" (2002), namely "An abrupt climate change occurs when the climate system is forced to transition to a new state at a rate that is determined by the climate system itself, and which is more rapid than the rate of change of the external forcing". The distinction between rapid and abrupt changes in our dataset is not possible at this time, but it is the main aim of our multi-proxy study. On the basis of earlier published paleolimnological studies in this region, rapid climate changes are expected around 12,800 (Younger Dryas) and 11,500 cal yr BP (Late Glacial/Holocene boundary). Partly concordant with these ages, partly contrary to them, the siliceous algae record from TDB-1 showed the most remarkable changes in the aquatic ecosystem at ca. 12,800 and 10,400 cal yr BP. While the Younger Dryas reversal is explicit in our record, the beginning of the Holocene is not well marked. 
Abrupt climate changes during the Late Glacial in the Southern Carpathian Mountains 263

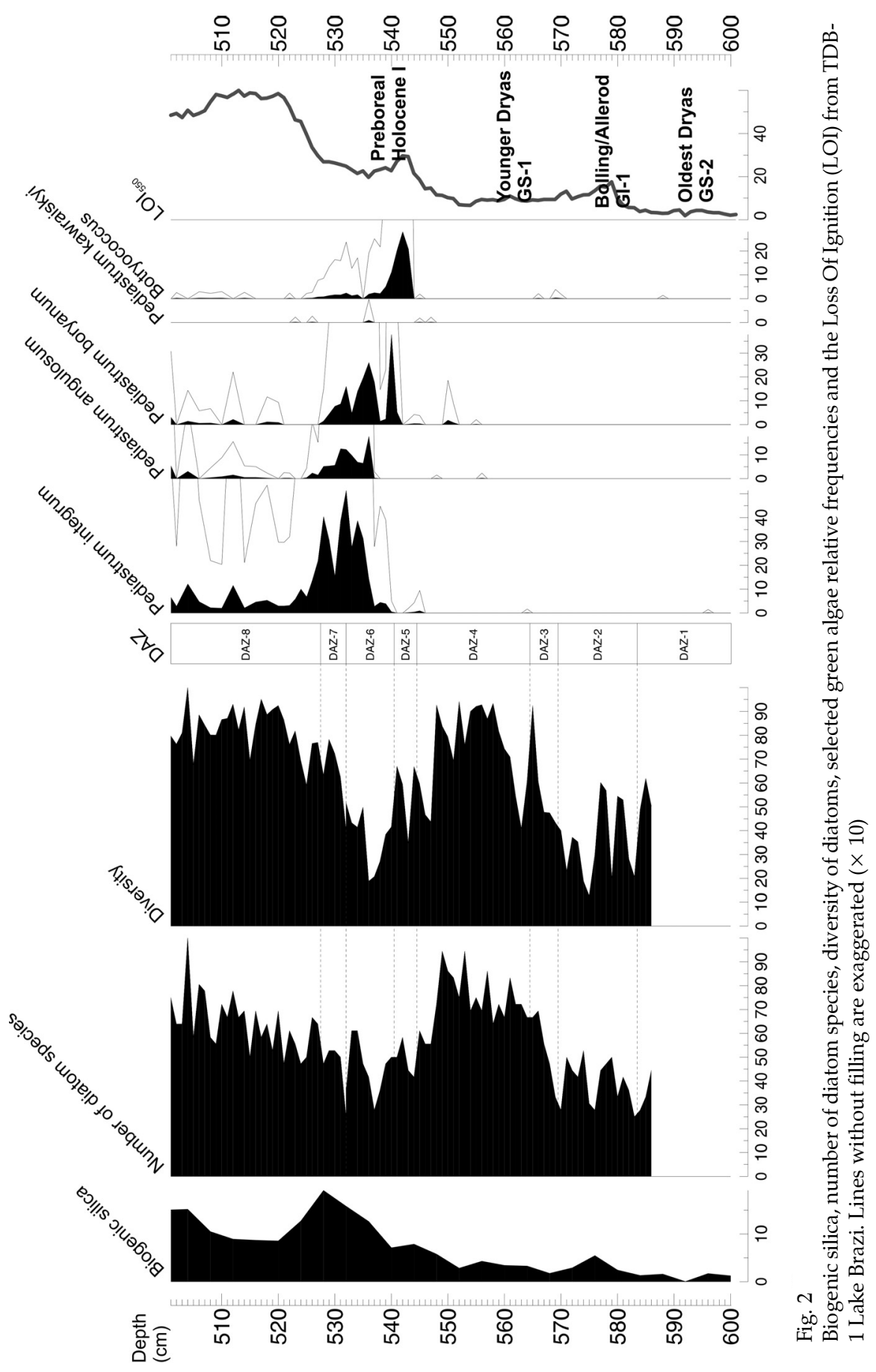

Central European Geology 52, 2009 
The Late Glacial history of Lake Brazi based on diatoms

A high-resolution diatom study from Lake Brazi pointed to pronounced, decadal to centennial scale fluctuation in the lake environment during the Late Glacial and the Early Holocene.

The first phase of lake development cannot be reconstructed by diatoms, because of poor preservation, but some eroded remains of large-celled diatoms infer the presence of a shallow lake, directly after the retreat of the Capra-Judele glacier from the Gales-valley, during the Oldest Dryas (GS-2; Björck et al. 1998). High relative frequency of aerophilic taxa indicated a high influx of allochthonous material during this period.

Between ca. 14,000 and 12,900 cal yr BP, small alkalophilous diatoms were dominant that usually inhabit the sediment surface and indicate shallow lake conditions. The lake diatom assemblage signaled an abrupt change at ca. $12,900-12,800$ cal yr BP, when a slightly acidophilous diatom assemblage overgrew the alkalophilous taxa. There are several possible explanations for this change. Probably the sharp change of the diatom assemblage was caused by cooling during the Younger Dryas with extended winter ice cover. In a cooling scenario, prolonged ice cover prevents the escape of dissolved $\mathrm{CO}_{2}$ to the atmosphere, in addition to inhibiting light penetration and thus the drawdown of $\mathrm{CO}_{2}$ through photosynthetic activity. The resultant increase in the concentration of $\mathrm{CO}_{2}$ in the lake causes a decline in $\mathrm{pH}$ through the production of carbonic acid, or $\mathrm{H}_{2} \mathrm{CO}_{3}$ (Wolfe 2002), providing conditions more favorable for the slightly acidophilous to circumneutral diatom taxa. Another plausible explanation is connected to soil development that began with considerable delay during the Bølling/Allerød interstadial and likely led to soil leaching and podzol formation by the onset of the Younger Dryas; locally this did not result in the extirpation of the coniferous tree population (Magyari et al. this issue) and local ecosystem productivity did not decrease considerably, according to the organic content measurements (Magyari et al., this issue). Humic acids washed into the lake may have caused acidification of the lake water. A third, possible scenario for the short-term (500 years) lake water acidification is increased fire intensity with the onset of the Younger Dryas. This was recorded by the microcharcoal accumulation rate curve (Magyari et al.. in prep).

Between 12,781-12,300 cal yr BP the diatom species replace each other quite often, suggesting that the environment was unstable or unpredictable, and the competition could have been strong for the available resources. In the ecology the so-called "r strategists" or r-selection have a small body-size. The diversity and number of taxa (Fig. 2) are also high in this zone. The reduced cell-size corresponds with low biogenic silica content in DAZ-4. We infer cold, slightly alkaline shallow pond conditions. Note that this zone corresponds to the second part of the Younger Dryas, but also extends to the Early Holocene (from ca. 11,500 cal yr BP). The observed frequent changes in the diatom flora may bear a relationship to the high amplitude warming in this period, which in the lake 
water triggered changes, but with a delay, most probably due to the increased input of glacier melt water and consequently subsistent cold lake water conditions (lake water in such cases is in disequilibrium with air temperature). A similar phenomenon was found in the Swiss Alps, where the Late Glacial and Early Holocene chironomid assemblages suggested persistent cold-water conditions for centuries even after the regional vegetation already pointed to warming (Ilyashuk et al. 2009).

Between 12,300 and 11,050 cal yr BP rich diatom assemblages were detected, suggesting a stable environment in which abiotic stress was reduced and the biotic interfaces could regulate the assemblages - as shown by the high taxarichness and diversity.

Between 10,901-10,514 cal yr BP the green algae probably responded to increasing lake water temperature in the growing season and accelerated nutrient input with the increase of soil temperatures. Planktonic habitats also increased, probably reflecting gradually increasing lake level in this zone.

For a better interpretation of the main changes in this period further analyses are needed, such as biomass calculation and selective counting of the large valves. The high biogenic silica content with the presence of large-body-sized, socalled 'k-strategist' diatoms probably responded to increasing lake water temperature in the growing season and/or the longer vegetation period.

Between 11,050 and 10,050 the productivity of the lake gradually increased, as can be inferred not only from the biogenic silica content that measures siliceous algae abundance, but also from the increasing abundance of green algae (Pediastrum spp. and Botryococcus sp.). From 10,050 cal yr BP the water of the lake became more acidic, and a peat-bog, probably similar to the recent floating Sphagnum carpet, grew along the shore of the lake.

\section{Biogenic silica}

Biogenic silica content reflects the biomass of diatoms and cysts that is a simple indicator of past siliceous algal production. In our study, the biogenic silica content was low during the Late Glacial, increased in the Pre-Boreal, peaked in the Early Holocene (in DAZ-7 and DAZ-8), but remained less than 10\% during the studied period. The flourish of siliceous algae occurred during the Middle and Late Holocene (see Magyari et al. in this issue).

\section{Diatom diversity}

In this stage of our study, the most adventurous and most problematic part of the paleoenvironmental reconstruction was the taxonomical difficulty, especially in the older layers in the case of glacial lakes of Retezat. Above we have presented some examples for the difficulties that partly derived from the climate-driven floristic changes of the diatom assemblages. Analogies to the Late Glacial flora of 
Lake Brazi can be found in arctic regions which, although they have been intensively studied recently, can be regarded as poorly-known regions (Fallu et al. 2000; Siver et al. 2005; Antoniades et al. 2008). While the investigation of diatoms has a history of more than 200 years in Europe, arctic diatoms have been the focus of interest for only 20-30 years. This intensive research resulted in many new taxa as well as monographs (Fallu et al. 2000; Antoniades et al. 2008; Esposito et al. 2008) proving that solving taxonomical problems require further effort for a long time. This extremely high taxonomic diversity relates to the problem of distribution of diatoms. Species that are generalists have broad ecological tolerance and consequently wide distribution, while species that are specialists have more exacting requirements and as a consequence they can occur only at a few locations (Poulickova et al. 2008). It seems that we must accept the indicator values and tolerance levels of the arctic species in our reconstruction, because most of the diatom taxa recorded in the Late Glacial part of Lake Brazi did not survive in the Retezat Mountains during the Holocene.

The growing database of the arctic region gives us a chance for diatom-based climate reconstruction. In this paper we focused on the Late Glacial part of the core, but naturally we plan the detailed analysis of siliceous remains of the Holocene deposits. For the last 10-11 thousand years paleoenvironmental reconstruction can be further refined by applying a calibration set obtained from glacier lakes and mires of the Retezat Mts. The calibration set is essential for the quantitative reconstruction. To build a detailed calibration set, collecting samples from surface sediments, mosses, rocks and other habitats of glacial lakes in Retezat Mountains is needed not only for diatoms, but also for chironomids, Cladocera, other algal groups.

\section{Acknowledgements}

This paper is part of the PROLONGE project (Providing long environmental records of Late Quaternary climatic oscillations in the Retezat Mountains). We are grateful for the support of the Hungarian Scientific Fund (OTKA PD73234 and 43078). This is Hungarian Academy of Sciences - Hungarian Natural History Museum Paleo Contribution No. 118.

\section{References}

Antoniades, D., P.B. Hamilton, M.S.V. Douglas, J.P. Smol 2008: Diatoms of North America: The Freshwater Floras of Prince Patrick, Ellef Ringnes and northern Ellesmere Islands from the Canadian Arctic Archipelago. - In: Lange-Bertalot, H. (Ed.): Iconographia Diatomologica, 17. A.R.G. Gantner Verlag K.G. 649 pp.

Batterbee, R.W. 1986: Diatom analysis. - In: Berglund, B.E. (Ed.): Handbook of Holocene Palaeoecology and Palaeohydrology. John Wiley and Sons, Chichester, New York, Brisbane, Toronto, Singapor, pp. 527-570.

Bennett K.D. 2005: Psimpoll Manual. - < http://www.kv.geo.uu.se/psimpoll.html > (accessed 12th February 2008). 
Björck, S., M.J.C. Walker, L.C. Cwynar, S. Johnsen, K.L. Knudsen, J.J. Lowe, B. Wohlfarth and intimate members 1998: An event stratigraphy for the Last Termination in the North Atlantic region based on the Greenland ice-core record: a proposal by the INTIMATE group. - Journal of Quaternary Science, 13, pp. 283-292.

Buczkó, K., E.K. Magyari, M. Braun, M. Bálint 2009: Late Glacial and Holocene diatoms from glacial lake Taul dintre Brazi, Retezat Mts, Romania. - In: Lotter, A., H. Cremer, M. Mullen, R. Vasiliauskiené, H. Hooghart (Eds): The joint 40th Meeting of the Dutch-Flemish Society of Diatomists (NVKD) and 3rd Cetral Europen Diatom Meeting (CE-DiatoM). Utrecht, Hollandia, 2009.03.26-2009.03.29. pp. 36-39.

Buczkó, K., N. Ognjanova-Rumenova, E. Magyari 2010: Taxonomy, morphology and distribution of some Aulacoseira taxa in glacial lakes in the South Carpathian region. - Polish Botanical Journal, 55, pp. 149-163.

Clarke, G., M. Kernan, A. Marchetto, S. Sorvari, J. Catalan 2005: Using diatoms to assess geographical patterns of biological and limnological change in high-altitude European lakes from pre-industrial times to the present day. - Aquatic Sciences, 67, pp. 224-236.

Committee on Abrupt Climate Change, National Research Council. 2002: "Definition of Abrupt Climate Change". Abrupt climate change : inevitable surprises. Washington, D.C.: National Academy Press. ISBN 9780309074346.

Esposito, R.M.M., S.A. Spaulding, D.M. McKnight, B. Van de Vijver, K. Kopalová, D. Lubinski, B. Hall, T. Whittaker 2008: Inland diatoms from the McMurdo Dry Valleys and James Ross Island, Antarctica - Botany, 86, pp. 1378-1392.

Fallu, M.A., N. Allaire, R. Pienitz 2000: Freshwater Diatoms from northern Québec and Labrador (Canada). Species-environment relationships in lakes of boreal forest, forest-tundra and trunda regions. - In: Lange-Bertalot, H., P. Kociolek (Eds): Bibliotheca Diatomologica 45. J. Cramer Series.

Heiri, O., A.F. Lotter, G. Lemcke 2001: Loss on ignition as a method for estimating organic and carbonate content in sediments: reproducibility and comparability of results. - Journal of Paleolimnology, 25, pp. 101-110.

Ilyashuk, B., E. Gobet, O. Heiri, A.F. Lotter, J.FN. van Leeuwen, W.O. van der Knaap, E. Ilyashuk, F. Oberli, B. Ammann 2009: Late Glacial environmental and climatic changes at the Maloja Pass, Central Swiss Alps, as recorded by chironomids and pollen. - Quat Sci Rev., 28, pp. 1340-1353. Lotter, A.F. 2003: Multi-proxy climatic reconstructions. - In: MacKay, A., R. Battarbee, J. Birks, F. Oldfield (Eds): Global Change in the Holocene. Arnold, London pp. 373-383.

Lotter, A.F., H.J.B. Birks, W. Hofmann, A. Marchetto 1997: Modern Diatom, Cladocera, Chironomid, and Chrysophyte cyst assemblages as quantitative indicators for the reconstruction of past environmental conditions in the Alps. I. Climate. - Journal of Paleolimnology, 18, pp. 395-420.

Lotter, A.F., H.J.B. Birks, W. Hofmann, A. Marchetto 1998: Modern Diatom, Cladocera, Chironomid, and Chrysophyte cyst assemblages as quantitative indicators for the reconstruction of past environmental conditions in the Alps. II. Nutrients. - Journal of Paleolimnology, 19, pp. $443-463$.

Mackay, A.W., D.B. Ryves, R.W. Battarbee, R.J. Flower, D. Jewson, P. Rioual, M. Sturm 2005: 1000 years of climate variability in central Asia: assessing the evidence using Lake Baikal (Russia) diatom assemblages and the application of a diatom-inferred model of snow cover on the lake. - Global and Planetary Change, 46, pp. 281-297

Mann, D.G., S.J. Thomas, K.M. Evans 2008: Revision of the diatom genus Sellaphora: a first account of the larger species in the British Isles. - Fottea, 8, pp. 15-78.

Magyari, E.K., M. Braun, K. Buczkó, K. Hubay, M. Bálint 2009: Radiocarbon chronology of glacial lake sediments in the Retezat Mts (S Carpathians, Romania): a window to Lateglacial and Holocene climatic and palaeoenvironmental changes. - Central European Geology, 52, pp. $225-248$. 
Magyari, E.K., G. Jakab, M. Braun, M. Bálint, K. Buczkó: Rapid responses of high-mountain vegetation to Lateglacial and Early Holocene climatic oscillations - a case study from the South Carpathian Mountains, Romania. in prep

Péterfi, L. St. 1974: Preliminary notes on the subfossil and recent diatom flora of the Zanoguta peat bog from the Retezat Mountains. - Studia Universitatis Babes-Bolyai, Cluj, Series Biologia, 19, pp. 5-17.

Pienitz, R, J.P. Smol, H.J.B. Birks 1995: Assessment of freshwater diatoms as quantitative indicators of past climatic change in the Yukon and Northwest Territories, Canada. - Journal of Paleolimnology, 13, pp. 21-49.

Poulícková, A., J. Špacková, M.G. Kelly, Duchoslav, D.G. Mann 2008: Ecological variation within Sellaphora species complexes (Bacillariophyceae): specialists or generalists? - Hydrobiologia, 614, pp. 373-386.

Reuther, A.U., P. Urdea, C. Geiger, S. Ivy-Ochs, H.P. Nille, P.W. Kubik, K. Heine 2007: Late Pleistocene glacial chronology of the Pietrele Valley, Retezat Mountains, Southern Carpathians constrained by $10 \mathrm{Be}$ exposure ages and pedological investigations. - Quaternary International, 164-65, pp. $151-169$.

Ryves, D.B., R. Battarbee, S.C. Fritz 2009: The dilemma of disappearing diatoms: incorporating dissolution into paleoenvironmental modelling and reconstructions. - Quaternary Science Reviews, 28, pp. 120-136.

Schmidt, R., C. Kamenik, C. Kaiblinger, M. Hetzel 2004:Tracking Holocene environmental changes in an alpine lake sediment core: application of regional diatom calibration, geochemistry, and pollen. - Journal of Paleolimnology, 32, pp. 177- 196.

Schmidt, R., C. Kamenik, R. Tessadri, K.A. Koinig 2006: Climatic changes from 12,000 to 4,000 years ago in the Austrian Central Alps tracked by sedimentological and biological proxies of a lake sediment core. - Journal of Paleolimnology, 35, pp. 491-505.

Siver, P.A., P.B. Hamilton, K. Stachura-Suchoples, J.P. Kociolek 2005: Diatoms of North America: The freshwater flora of Cape Cod, Massachusetts, USA. - In: Lange-Bertalot, H. (Ed.): Iconographia diatomologica, vol. 14. Koeltz Scientific Books, Koeningstein, Liechtenstein.

Smol, J.P. 2008: Pollution of Lakes and Rivers: A Paleoenvironmental Perspective - 2nd Edition. Blackwell Publishing, Oxford. $383 \mathrm{p}$

Stoermer, E.F., J.P. Smol (Eds) 1999: The diatoms: Applications for the environmental and Earth Sciences. - Cambridge University Press, Cambridge.

Wolfe, A.P. 2002: Climate modulates the acidity of Arctic lakes on millennial time scales. - Geological Society of America, 30, pp. 215-218. 